ISSN 1392-3196 / e-ISSN 2335-8947

Zemdirbyste-Agriculture, vol. 104, No. 2 (2017), p. 123-130

DOI 10.13080/z-a.2017.104.016

\title{
The influence of foliar fertilization with nitrogen, sulphur, amino acids and microelements on spring wheat
}

\author{
Gediminas STAUGAITIS ${ }^{1}$, Loreta ALEKNAVIČIENE ${ }^{2}$, Zita BRAZIENE ${ }^{2}$, \\ Antanas MARCINKEVIČIUS ${ }^{2}$, Virgilijus PALTANAVIČIUS ${ }^{1}$ \\ ${ }^{1}$ Agrochemical Laboratory, Lithuanian Research Centre for Agriculture and Forestry \\ Savanorių 287, Kaunas, Lithuania \\ E-mail: agrolab@agrolab.lt \\ ${ }^{2}$ Rumokai Experimental Station, Lithuanian Research Centre for Agriculture and Forestry \\ Rumokai, Vilkaviškis distr., Lithuania
}

\begin{abstract}
During a five year period (2011-2015) research was carried out with spring wheat on a Bathihypogleyi-Calc(ar)ic Luvisol (LVk-gld-w) with predominant silt loam on clay loam. The main aim was to establish how different foliar fertilizers affect spring wheat when the optimum nitrogen $(\mathrm{N})$, phosphorus $(\mathrm{P})$, potassium $(\mathrm{K})$ and sulphur $(\mathrm{S})$ rates had been applied during the main fertilisation. The soil was well-drained and very high in plant-available phosphorus $\left(\mathrm{P}_{2} \mathrm{O}_{5}\right)$ and potassium $\left(\mathrm{K}_{2} \mathrm{O}\right), \mathrm{pH}_{\mathrm{KCl}}$ 6.4-7.4. Each year, depending on agrochemical analyses done in spring, all treatments were applied with the same rates of mineral fertilizers. The experiments established that the foliar nutrition of spring wheat at the $\mathrm{BBCH} 29-30$ stage with amino acids with amide nitrogen (Delfan $2.01 \mathrm{ha}^{-1}$ ) or microelements (Tradecorp Cu $0.8 \mathrm{~kg} \mathrm{ha}^{-1}$, Tradecorp Mn $1.0 \mathrm{~kg} \mathrm{ha}^{-1}$ and Tradecorp Zn $1.0 \mathrm{~kg} \mathrm{ha}^{-1}$ ) increased grain yield only in one year out of five, and ammonium sulphate $\left(15.0 \mathrm{~kg} \mathrm{ha}^{-1}\right)$ and urea $\left(6.7 \mathrm{~kg} \mathrm{ha}^{-1}\right)$ in two years. The average data of five years indicated that the foliar fertilisers used did not increase grain and straw yield statistically significantly and did not have significant influence on the content of crude protein and starch in grain.
\end{abstract}

Key words: amino acids, foliar fertilisers, microelements, nitrogen, spring wheat, sulphur.

\section{Introduction}

Top dressing through leaves has been used for quite a while in order to provide plants additionally with deficient chemical elements, especially microelements (Wójcik, 2004). It is effective, when plants develop poorly or suffer from the deficiency of a plant nutrient (Malhi et al., 2005). However, there is no finalised evidence how foliar fertilization acts under the conditions of intensive agriculture when soil is fertile, cultivated and balanced fertilization is applied according to agrochemical analyses of soil. Researchers have indicated that there is no need to apply foliar fertilization if soil conditions for plants are favourable and nutrition is optimum (Breuer et al., 2003). Meanwhile, even under such conditions additional fertilization through leaves can reduce the stresses caused by climatic factors, which occur during plant growing period, therefore, some researchers indicate that the use of foliar fertilizers is an urgent response to the changes in the environment and within a plant, and such fertilization becomes an integral part of intensive farming (Babaeian et al., 2010; Sepiedeh et al., 2014; Begum et al., 2015). While plants assimilate nitrogen and sulphur, it is important how the mineralisation of organic matter and plant residues, which is closely related to the weather conditions, takes place in the soil (Sierra et al., 2015). If this process is slow and plants suffer stresses, foliar fertilization with amide nitrogen or amino acids is favourable (Staugaitis, Petrauskienè, 2006).

It is important not to be late with this fertilization and to perform it at the tillering stage as insufficient supply of cereals with nitrogen results in poor formation of lateral shoots and fewer grains per ear (Imran, Gurmani, 2011). Good results are achieved by foliar spraying of spring wheat with nitrogen and sulphur fertilizers - ammonium sulphate, especially when there is low content of plantavailable sulphur in the soil (Staugaitienè et al., 2013); and ammonium sulphate increased spring barley yield more than urea (Staugaitis et al., 2014). Plants can suffer from the deficiency of microelements both when there is a lack of them in the soil and when unfavourable climatic conditions occur during the growing season: drought, excessive soil moisture and cold weather. When soil $\mathrm{pH}$ is $>7$ or there is a surplus of a certain microelement, this

Please use the following format when citing the article:

Staugaitis G., Aleknavičienė L., Brazienė Z., Marcinkevičius A., Paltanavičius V. 2017. The influence of foliar fertilization with nitrogen, sulphur, amino acids and microelements on spring wheat. Zemdirbyste-Agriculture, 104 (2): 123-130 DOI 10.13080/z-a.2017.104.016 
often results in the shortage of copper, zinc or manganese (Wójcik, 2004; Cakmak, 2008; Begum et al., 2015).

The influence of foliar fertilizers on different plants is unequal; it depends on a plant species and even on a variety (Fageria, Baligar, 2005; Fageria et al., 2006). Fertilization through leaves with amino acids, microelements and sulphur influences plants favourably and increases the productivity of spring barley (Staugaitis, Petrauskienė, 2006; Pranckietienè et al., 2015), sugar beet (Mekdad, Rady, 2016), potatoes (Brar, Kaur, 2006), maize (Peng et al., 2013) and vegetables (Bundinienè et al., 2007). The experiments indicated that the productivity of spring wheat was increased by foliar fertilization with nitrogen, potassium and zinc fertilizers (Guenis et al., 2003; Zafar et al., 2016). Spraying of spring barley with compound fertilizers results in the chlorophyll increase three days after application (Staugaitis, Pečkyte, 2008).

The aim of our research was to investigate the influence of fertilizers of different composition containing nitrogen, sulphur, amino acids and microelements on the yield and quality of spring wheat. A fertile type of soil was chosen for the research where balanced fertilization was applied according to soil agrochemical analyses; foliar fertilization was carried out at the $\mathrm{BBCH} 29-30$ stage. The experiments were carried out in the same field but in its different spots for five years.

\section{Materials and methods}

The field experiment was conducted in 20112015 at the Rumokai Experimental Station of the Lithuanian Research Centre for Agriculture and Forestry. During the experiment, spring wheat was fertilized with foliar fertilizers according to the following scheme: 1) control, no foliar fertilizer applied, 2) fertilized with nitrogen $(\mathrm{N})$ and sulphur (S) - ammonium sulphate $\left.15.0 \mathrm{~kg} \mathrm{ha}^{-1}\left(3.1 \mathrm{~kg} \mathrm{ha}^{-1} \mathrm{~N}, 3.5 \mathrm{~kg} \mathrm{ha}^{-1} \mathrm{~S}\right), 3\right)$ fertilized with amide nitrogen - urea $6.7 \mathrm{~kg} \mathrm{ha}^{-1}\left(3.1 \mathrm{~kg} \mathrm{ha}^{-1} \mathrm{~N}\right)$, 4) fertilized with copper $(\mathrm{Cu})$, manganese $(\mathrm{Mn})$ and zinc (Zn) with EDTA - Tradecorp Cu $0.8 \mathrm{~kg} \mathrm{ha}^{-1}$, Tradecorp Mn $1.0 \mathrm{~kg} \mathrm{ha}^{-1}$ and Tradecorp Zn $1.0 \mathrm{~kg} \mathrm{ha}^{-1}$ (116 $\mathrm{g} \mathrm{ha}^{-1}$ $\mathrm{Cu}, 130 \mathrm{~g} \mathrm{ha}^{-1} \mathrm{Mn}, 140 \mathrm{~g} \mathrm{ha}^{-1} \mathrm{Zn}$ ), 5) fertilized with amide nitrogen and amino acids - Delfan $2.01 \mathrm{ha}^{-1}, 6$ ) fertilized with ammonium sulphate $15.0 \mathrm{~kg} \mathrm{ha} \mathrm{kg}^{-1}$, Tradecorp $\mathrm{Cu}$ $0.8 \mathrm{~kg} \mathrm{ha}^{-1}$, Tradecorp Mn $1.0 \mathrm{~kg} \mathrm{ha}^{-1}$, Tradecorp $\mathrm{Zn}$ $1.0 \mathrm{~kg} \mathrm{ha}^{-1}$, Delfan $2.01 \mathrm{ha}^{-1}$, i.e. with all fertilizers together, which were used in treatments 2, 4 and 5.

The composition of fertilizers used for foliar nutrition was as follows: ammonium sulphate $\left(\left(\mathrm{NH}_{4}\right)_{2} \mathrm{SO}_{4}\right)$ $-20.5 \% \mathrm{~N}$ and $23.5 \% \mathrm{~S}$, urea $\left(\mathrm{CO}\left(\mathrm{NH}_{2}\right)_{2}\right)-46.1 \% \mathrm{~N}$, Delfan $-4.4 \%$ organic nitrogen $\left(\mathrm{N}_{\text {org }}\right)$, Tradecorp $\mathrm{Cu}$ $-14.5 \% \mathrm{Cu}$ with EDTA, Tradecorp Mn - 13.0\% Mn with EDTA and Tradecorp Zn $-14.0 \%$ Zn with EDTA. According to the experimental design, the plants were foliar-fertilized at the BBCH 29-30 stage.

During the main fertilization in spring and supplementary fertilization during wheat growing season, equal rates of NPK fertilizers were applied as indicated in Table 1. Each year, while estimating fertilizer rates the content of mineral $\mathrm{N}$, plant-available phosphorus $\left(\mathrm{P}_{2} \mathrm{O}_{5}\right)$ and potassium $\left(\mathrm{K}_{2} \mathrm{O}\right)$ in the soil was taken into account and was used at the same time a fertilizing programme "Rational Fertilization" by the Agrochemical Research Laboratory of Lithuanian Research Centre for Agriculture and Forestry. A target yield of spring wheat was $5 \mathrm{tha}^{-1}$.
In spring, before crop sowing the total estimated rates of phosphorus and potassium were applied and $40 \mathrm{~kg} \mathrm{ha}^{-1}$ of the estimated $\mathrm{N}$ fertilizer rate were applied for spring wheat at the BBCH 31 stage. The spring wheat was fertilized with ammonium nitrate, potassium chloride and diammonium phosphate.

Table 1. Fertilization of spring wheat with nitrogen $(\mathrm{N})$, phosphorus $\left(\mathrm{P}_{2} \mathrm{O}_{5}\right)$ and potassium $\left(\mathrm{K}_{2} \mathrm{O}\right)$

\begin{tabular}{|c|c|c|c|c|}
\hline \multirow{3}{*}{ Year } & \multicolumn{4}{|c|}{ Fertilization $\mathrm{kg} \mathrm{ha}^{-1}$} \\
\hline & \multicolumn{2}{|c|}{$\mathrm{N}$} & $\mathrm{P}_{2} \mathrm{O}$ & $\mathrm{K}_{2} \mathrm{O}$ \\
\hline & pre-sowing & supplementary & \multicolumn{2}{|c|}{ pre-sowing } \\
\hline 2011 & 119 & 40 & 13 & 68 \\
\hline 2012 & 96 & 40 & 0 & 37 \\
\hline 2013 & 13 & 40 & 8 & 68 \\
\hline 2014 & 103 & 40 & 8 & 68 \\
\hline 2015 & 105 & 40 & 18 & 68 \\
\hline
\end{tabular}

Soil samples for determination of $\mathrm{pH}$, plantavailable $\mathrm{P}_{2} \mathrm{O}_{5}$ and $\mathrm{K}_{2} \mathrm{O}$ content were collected from 0-20 cm soil layer of every replication from March 19 to April 20. At the same time soil samples were collected from 0-30 and 30-60 cm soil layers for the determination of the mineral nitrogen $\left(\mathrm{N}_{\text {min }}\right)$ and mineral sulphur $\left(\mathrm{S}_{\min }\right)$ content. Soil $\mathrm{pH}$ was determined in $1 \mathrm{~N} \mathrm{KCl}$ extraction using a potentiometric method (ISO 10390:2005), plant-available $\mathrm{P}_{2} \mathrm{O}_{5}$ and $\mathrm{K}_{2} \mathrm{O}$ content - Egner-RiehmDomingo (A-L) method, $\mathrm{N}_{\min }$ and $\mathrm{S}_{\min }$ content - in $1 \mathrm{M}$ $\mathrm{KCl}$ extract (sample to solution ratio 1:2.5) using the colorimetric method. Plant-available microelements in the soil were determined as follows: $\mathrm{Mn}$ in $0.05 \mathrm{M}$ $\mathrm{H}_{2} \mathrm{SO}_{4}$ extraction (solution rate $1: 10$ ), $\mathrm{Zn}$ - in ammonium acetate extraction at $\mathrm{pH} 4.8, \mathrm{Cu}-$ in $1 \mathrm{M} \mathrm{HCl}$ extraction (solution rate 1:10), boron (B) - in hot water extraction and molybdenum (Mo) - in ammonium oxalate extraction at $\mathrm{pH} 3.3$ (solution rate $1: 10$ ).

The total size of the experimental plot was $36.0 \mathrm{~m}^{2}$, harvested area $26.4 \mathrm{~m}^{2}$. Four replications of each treatment were used; a randomised experimental design was applied. Spring wheat variety 'Triso' was cultivated; it was sown on April 10-26.

For weed control, at the end of the tillering (BBCH28-29) stage the following herbicide combinations were used: in 2011 - Banvel $0.151 \mathrm{ha}^{-1}+$ MCPA Nufarm $0.71 \mathrm{ha}^{-1}$, in 2012-2014 - Sekator $0.151 \mathrm{ha}^{-1}+\mathrm{MCPA}$ Nufarm $0.81 \mathrm{ha}^{-1}$, in 2015 - Sekator $0.151 \mathrm{ha}^{-1}+$ MCPA Nufarm 0.71 ha $^{-1}$. In 2011-2013 growth regulator Cerone $0.51 \mathrm{ha}^{-1}$ was used for spring wheat at the BBCH 39 stage, in 2014 Moddus $0.151 \mathrm{ha}^{-1}+$ Cycocel $0.31 \mathrm{ha}^{-1}$ was sprayed at the BBCH 29 stage, and in 2015 - Moddus $0.151 \mathrm{ha}^{-1}$. In 2012-2013, the wheat was sprayed against diseases at BBCH 65 stage with fungicide Prosaro $11 \mathrm{ha}^{-1}$, in 2014 - with Orius $1.01 \mathrm{ha}^{-1}+$ Taspa $0.351 \mathrm{ha}^{-1}$, and in 2015 fungicide Tango Super $11 \mathrm{ha}^{-1}$ was used at the BBCH 29 stage and Orius $1.01 \mathrm{ha}^{-1}+$ Taspa $0.351 \mathrm{ha}^{-1}$ at the BBCH 65 stage.

The spring wheat was harvested on August 14-24. Before harvesting, wheat plant samples were taken from four spots of each plot within $0.25 \mathrm{~m}^{2}$ area for the determination of productivity indicators. The grain collected from each experimental plot was weighed separately, grain moisture content and cleanness were determined, and grain and straw samples from replications 1 and 3 were collected for the determination of quality 
parameters. Spring wheat grain yield was expressed in moisture of $14 \%$ absolutely clean and air dried seed, straw yield - on absolutely dry matter. Total $\mathrm{N}$ content in plants was determined using Kjeldahl method; the total Kjeldahl $\mathrm{N}$ content multiplied by 6.25 gave the crude protein content. Starch content was determined using a polarimeter Polax21 (Atago Co. Ltd, Japan).

Statistical analyses of yield and plant biometric data were performed using the analysis of variance (ANOVA).

Table 2. The agrochemical properties of soil, 2011-2015
Soil. The experiment was conducted on a Bathihypogleyi-Calc(ar)ic Luvisol (LVk-gld-w). Soil texture was silt loam on loam and clay loam. The top of the carbonate horizon and the gleyicity traces were determined at the $60 \mathrm{~cm}$ depth. The soil and its agrochemical properties are presented in Table 2 . The $\mathrm{pH}$ value in the arable soil layer ranged from 6.4 to $7.4 . \mathrm{N}_{\text {min }}$ and $\mathrm{S}_{\min }$ levels in 0-60 cm soil layer ranged from very high to very low. The content of plant-available $\mathrm{P}_{2} \mathrm{O}_{5}$ at the $0-20 \mathrm{~cm}$ layer was very high and extreme and the content of plant-available $\mathrm{K}_{2} \mathrm{O}$ was high and very high.

\begin{tabular}{|c|c|c|c|c|c|c|c|c|c|c|}
\hline \multirow[b]{3}{*}{ Properties } & \multicolumn{10}{|c|}{ Year } \\
\hline & \multicolumn{2}{|c|}{2011} & \multicolumn{2}{|c|}{2012} & \multicolumn{2}{|c|}{2013} & \multicolumn{2}{|c|}{2014} & \multicolumn{2}{|c|}{2015} \\
\hline & content & $\begin{array}{c}\text { group of } \\
\text { nutrient } \\
\text { content } \\
\text { level }\end{array}$ & content & $\begin{array}{c}\text { group of } \\
\text { nutrient } \\
\text { content } \\
\text { level }\end{array}$ & content & $\begin{array}{c}\text { group of } \\
\text { nutrient } \\
\text { content } \\
\text { level }\end{array}$ & content & $\begin{array}{c}\text { group of } \\
\text { nutrient } \\
\text { content } \\
\text { level }\end{array}$ & content & $\begin{array}{c}\text { group of } \\
\text { nutrient } \\
\text { content } \\
\text { level }\end{array}$ \\
\hline $\mathrm{pH}_{\mathrm{KCl}}$ & 6.4 & $\mathrm{~V}$ & 6.7 & $\mathrm{~V}$ & 6.9 & $\mathrm{~V}$ & 7.0 & $\mathrm{~V}$ & 7.4 & $\mathrm{~V}$ \\
\hline Plant-available $\mathrm{P}_{2} \mathrm{O}_{5} \mathrm{mg} \mathrm{kg}^{-1}$ & 256 & V & 388 & VI & 275 & V & 279 & $\mathrm{~V}$ & 239 & V \\
\hline Plant-available $\mathrm{K}_{2} \mathrm{O} \mathrm{mg} \mathrm{kg}^{-1}$ & 183 & IV & 272 & $\mathrm{~V}$ & 204 & V & 209 & $\mathrm{~V}$ & 185 & IV \\
\hline $\mathrm{N}_{\min } 0-30 \mathrm{~cm} \mathrm{~kg} \mathrm{ha}^{-1}$ & 18.6 & & 43.8 & & 57.4 & & 31.5 & & 19.9 & \\
\hline $30-60 \mathrm{~cm} \mathrm{~kg} \mathrm{ha}^{-1}$ & 9.5 & & 32.8 & & 53.1 & & 24.8 & & 15.1 & \\
\hline $0-60 \mathrm{~cm} \mathrm{~kg} \mathrm{ha}^{-1}$ & 28.1 & I & 76.6 & III & 110.5 & IV & 56.3 & II & 35.0 & II \\
\hline $\mathrm{S}_{\min } 0-30 \mathrm{~cm} \mathrm{~kg} \mathrm{ha}^{-1}$ & 6.5 & & 2.9 & & 5.9 & & 10.8 & & 12.6 & \\
\hline $30-60 \mathrm{~cm} \mathrm{~kg} \mathrm{ha}^{-1}$ & 5.2 & & 2.7 & & 6.3 & & 9.5 & & 37.4 & \\
\hline $0-60 \mathrm{~cm} \mathrm{~kg} \mathrm{ha}^{-1}$ & 11.7 & II & 5.6 & I & 12.2 & II & 20.3 & IV & 50.0 & V \\
\hline
\end{tabular}

Note. $\mathrm{pH}, \mathrm{P}_{2} \mathrm{O}_{5}$ and $\mathrm{K}_{2} \mathrm{O}$ median determined using 8 composite samples, $\mathrm{N}_{\min }$ and $\mathrm{S}_{\min }-4$ composite samples; groups of nutrient content level: I - very low, II - low, III - medium, IV - high, V - very high, VI - extreme.

The microelement content in the arable soil layer ranged as follows: plant-available $\mathrm{B}$ levels were average and high $\left(0.42-1.18 \mathrm{mg} \mathrm{kg}^{-1}\right)$, plant-available $\mathrm{Cu}$ levels were average and high $\left(2.49-3.40 \mathrm{mg} \mathrm{kg}^{-1}\right)$, those of plant-available Mn were average and very high (78.4$129.3 \mathrm{mg} \mathrm{kg}^{-1}$ ), plant-available Mo - low and average (0.13-0.18 $\left.\mathrm{mg} \mathrm{kg}^{-1}\right)$, and plant-available $\mathrm{Zn} \mathrm{-} \mathrm{average}$ and high (1.93-3.07 $\left.\mathrm{mg} \mathrm{kg}^{-1}\right)$.
Weather conditions. In general, local climatic conditions are favourable for spring wheat cultivation; however, meteorological conditions of certain years have substantial influence on that. In 2011-2015 during wheat vegetation the mean daily temperature (Fig. 1) was higher compared with the same period in 1981-2010, and in certain years the rainfall (Fig. 2) was distributed very unevenly.

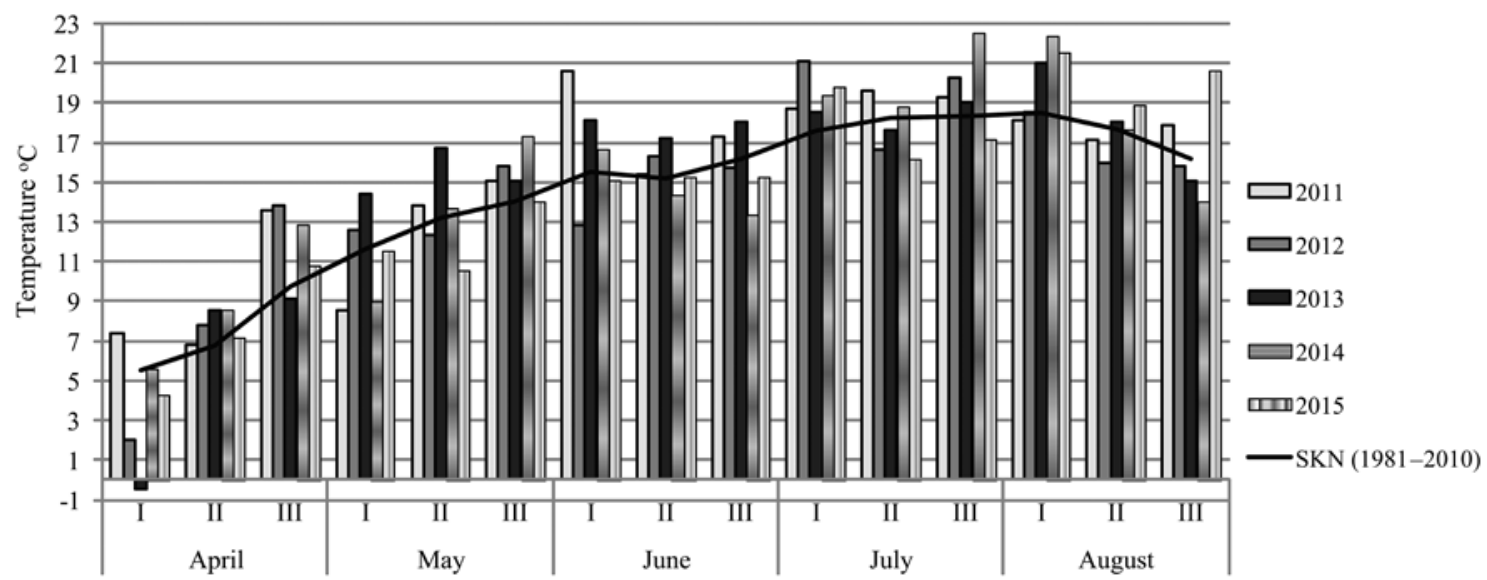

Figure 1. The mean daily temperature values of ten day periods during spring wheat growing season and climate normal (1981-2010) (Kybartai Meteorological Station)

In 2011, during the time of spring wheat development the mean daily temperature was close to the multiannual average, except for the first ten days of June which were extremely hot. At that time there was practically no rainfall and during tillering the plants suffered moisture deficiency for nearly two weeks.
Later the weather conditions were favourable for wheat; however, it was very rainy starting from the beginning of milk stage and during harvesting, the soil was wet and the grain in ears matured slowly.

In 2012, during the plant growing period the mean daily temperature was about $1{ }^{\circ} \mathrm{C}$ higher compared 


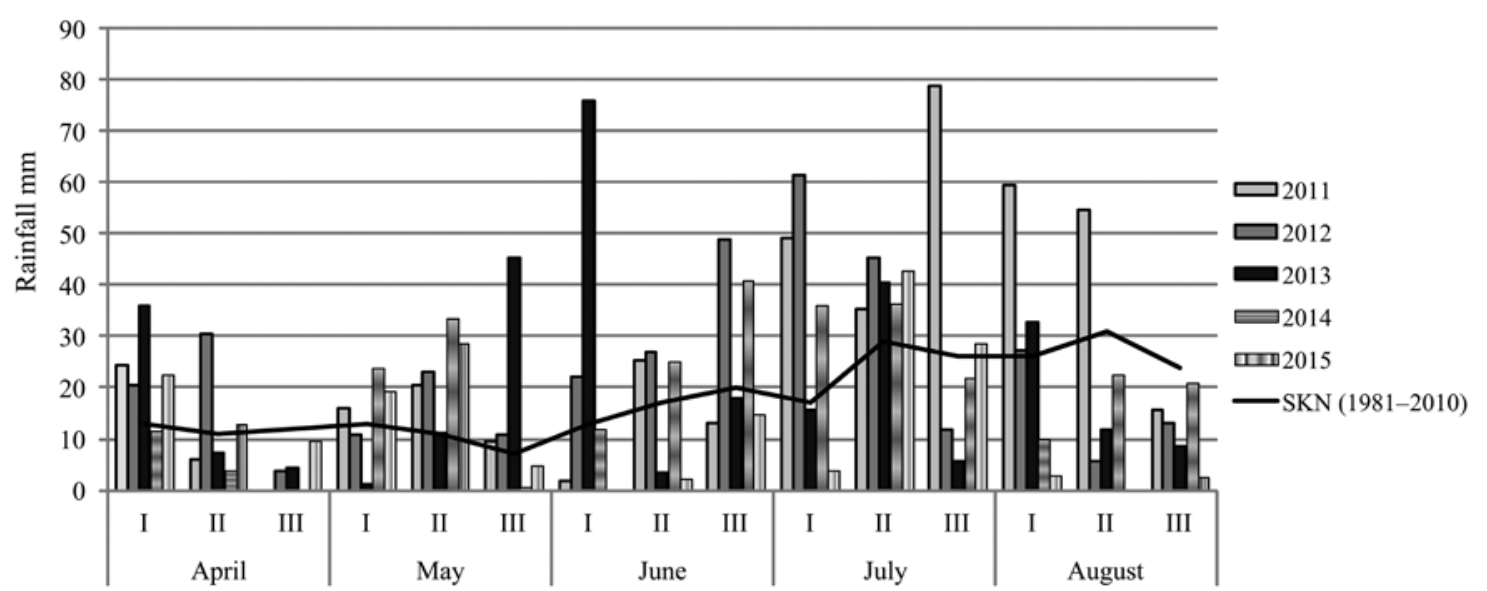

Figure 2. The amount of rainfall in ten day periods during spring wheat growing season and climate normal (19812010) (Kybartai Meteorological Station)

with the climate normal, nevertheless, moisture was sufficient for plants until the end of July. That year the spring wheat germinated and tillered well; the highest number of stems was obtained per unit of area. The dry weather that prevailed from the second half of July favoured grain maturity.

The year of 2013 was special for the fact that starting from the beginning of May and continuing for nearly the entire growing season of spring wheat the mean daily temperature was higher than the multiannual average; during certain ten day periods the difference accounted for $0.5-3^{\circ} \mathrm{C}$. The soil before sowing was normally moist; however, after sowing there was heavy rainfall (45.3 and $76.0 \mathrm{~mm}$, respectively) during the last ten days of May and the first ten days of June which damaged the crop. There was excess moisture in the soil which resulted in the formation of crust, plant roots suffered from oxygen deficiency, which affected the development of productive stems and their number was the lowest during the whole five-year period. Later the soil moisture was normal, heat for plants was sufficient; nevertheless, recurring rains in the middle of July influenced the spread of wheat ear disease Fusarium graminearum.

In 2014, during the spring wheat growing season the mean daily temperature was close to the multiannual average, moisture in the soil was sufficient; therefore, the plants germinated and tillered well. Some marginal drop of temperature was recorded during the third ten days of June, at that time as well as during the first and second ten days of July more abundant rainfall (36.0-41.0 mm) was observed. It had no influence on the spring wheat and starting from the end of July warm and dry weather prevailed which was favourable for grain maturation.

During the observation period of 2015 the weather was cooler and drier and that was the only year, when the mean daily temperature was lower that the multiannual average. In June and during the first half of July, the soil moisture supplies were on the verge of deficiency; however, it did not have any substantial influence on the plants. The crop was not dense, but the ears yielded more grain and they were substantially heavier compared with the other experimental years.

\section{Results}

The influence of foliar fertilization on spring wheat yield and productivity components - number of productive stems, number of grains per ear and 1000 grain weight are presented in Table 3 .

Foliar fertilization had no significant effect on the number of productive stems. According to the average data of 2011-2015, the foliar fertilization of spring wheat with $\mathrm{N}, \mathrm{S}$, amino acids and microelements (treatments 2-6) did not increase the number of productive stems statistically significantly. Only in 2014 the foliar fertilization with urea (treatment 3 ) increased the number of productive stems from 657 to 703 per $\mathrm{m}^{2}$, or by $7.0 \%$, with microelements (treatment 4 ) increased the number of productive stems from 657 to 707 per $\mathrm{m}^{2}$, or by $7.6 \%$, with fertilizer Delfan containing $\mathrm{N}_{\text {org }}$ and amino acids (treatment 5) - increased the number of productive stems from 657 up to 720 per $\mathrm{m}^{2}$, or by $9.6 \%$, and the fertilization with a complex fertilizer containing $\mathrm{N}, \mathrm{S}$, amino acids and microelements (treatment 6) increased the number of productive stems from 657 up to 774 per $\mathrm{m}^{2}$, or by $17.8 \%$. That was the year when prior to foliar fertilization there had been no rain during the third ten days of May and there was moisture deficiency in the soil, and the mean daily temperature was $17.3^{\circ} \mathrm{C}$ or $2.3^{\circ} \mathrm{C}$ higher compared with the multiannual average. A statistically significant increase in the number of productive stems was achieved in 2011 as well by foliar fertilization with microelements (treatment 4) - the number of productive stems increased from 594 to 638 per $\mathrm{m}^{2}$, or by $7.4 \%$. This fact shows that although during the five years foliar fertilisation statistically not increase the number of productive stems.

The evaluation of the influence of foliar fertilization carried out in 2011-2015 on the number of grains per ear and the 1000 grain weight did not yield statistically significant difference. However, the 1000 grain weight significantly increased from 35.48 to 36.55 $\mathrm{g}$ in 2011 and from 38.55 to $40.30 \mathrm{~g}$ in 2013 after foliar fertilization with ammonium sulphate (treatment 2). That year $\mathrm{S}_{\min }$ deficiency was recorded in the soil and fertilization with ammonium sulphate could have had influence on that.

While assessing the differences in wheat grain quality it was established that during all experimental years foliar fertilization did not have statistically significant influence on crude protein and starch content in grain Table 4. 
Table 3. The influence of foliar fertilization on spring wheat productivity indicators

\begin{tabular}{|c|c|c|c|c|c|c|c|c|}
\hline \multirow{2}{*}{ No. } & \multirow{2}{*}{ Treatment } & \multicolumn{5}{|c|}{ Year } & & \multirow{2}{*}{$\begin{array}{c}\text { Increase } \\
\%\end{array}$} \\
\hline & & 2011 & 2012 & 2013 & 2014 & 2015 & & \\
\hline \multicolumn{9}{|c|}{ Number of productive stems per $\mathrm{m}^{2}$} \\
\hline 1. & Control - without fertilizers & 594 & 749 & 574 & 657 & 564 & 627 & - \\
\hline & Ammonium sulphate & 599 & 752 & 590 & 640 & 580 & 632 & 0.8 \\
\hline & Urea & 591 & 743 & 577 & 703 & 565 & 636 & 1.3 \\
\hline & Tradecorp $\mathrm{Cu}+$ Tradecorp $\mathrm{Mn}+$ Tradecorp $\mathrm{Zn}$ & 638 & 755 & 592 & 707 & 558 & 635 & 1.3 \\
\hline & Delfan & 592 & 715 & 566 & 720 & 585 & 636 & 1.3 \\
\hline & $\begin{array}{l}\text { Ammonium sulphate }+ \text { Tradecorp Cu + } \\
\text { Tradecorp Mn }+ \text { Tradecorp Zn }+ \text { Delfan }\end{array}$ & 595 & 745 & 573 & 774 & 583 & 654 & 4.2 \\
\hline & $\mathrm{LSD}_{05}$ & 39.9 & 20.6 & 21.5 & 39.1 & 48.6 & 33.0 & \\
\hline \multicolumn{9}{|c|}{ Number of grains per ear } \\
\hline & Control - without fertilizers & 31 & 30 & 31 & 34 & 36 & 32 & - \\
\hline & Ammonium sulphate & 30 & 29 & 31 & 33 & 35 & 32 & 0 \\
\hline & Urea & 30 & 28 & 31 & 33 & 35 & 31 & -3.1 \\
\hline & Tradecorp $\mathrm{Cu}+$ Tradecorp $\mathrm{Mn}+$ Tradecorp $\mathrm{Zn}$ & 31 & 29 & 31 & 34 & 35 & 32 & 0 \\
\hline & Delfan & 31 & 29 & 30 & 34 & 36 & 32 & 0 \\
\hline & $\begin{array}{l}\text { Ammonium sulphate }+ \text { Tradecorp } \mathrm{Cu}+ \\
\text { Tradecorp Mn }+ \text { Tradecorp } \mathrm{Zn}+\text { Delfan }\end{array}$ & 30 & 30 & 30 & 34 & 35 & 32 & 0 \\
\hline & $\mathrm{LSD}_{05}$ & 1.1 & 1.5 & 1.153 & 2.8 & 2.9 & 0.6 & \\
\hline \multicolumn{9}{|c|}{1000 grain weight $g$} \\
\hline & Control - without fertilizers & 35.48 & 36.42 & 38.55 & 35.24 & 43.93 & 37.92 & - \\
\hline 2. & Ammonium sulphate & 36.55 & 35.61 & 40.30 & 35.58 & 43.51 & 38.31 & 0 \\
\hline & Urea & 36.19 & 36.61 & 38.71 & 34.92 & 43.36 & 37.96 & 0 \\
\hline & Tradecorp $\mathrm{Cu}+$ Tradecorp $\mathrm{Mn}+$ Tradecorp $\mathrm{Zn}$ & 36.50 & 35.73 & 39.34 & 35.39 & 43.28 & 38.05 & 0 \\
\hline 5. & Delfan & 36.19 & 35.22 & 39.19 & 35.52 & 42.92 & 37.81 & 0 \\
\hline & $\begin{array}{l}\text { Ammonium sulphate }+ \text { Tradecorp Cu }+ \\
\text { Tradecorp Mn }+ \text { Tradecorp } \mathrm{Zn}+\text { Delfan }\end{array}$ & 36.51 & 34.39 & 38.99 & 34.93 & 43.13 & 37.59 & 0 \\
\hline & $\mathrm{LSD}_{05}$ & 0.910 & 1.188 & 0.901 & 0.910 & 0.917 & 0.668 & \\
\hline
\end{tabular}

Table 4. The influence of foliar fertilization on quality indicators of spring wheat grain

\begin{tabular}{|c|c|c|c|c|c|c|c|c|c|c|}
\hline \multirow{3}{*}{ No. } & \multirow{3}{*}{ Treatment } & \multicolumn{5}{|c|}{ Crude protein $\% *$} & \multicolumn{4}{|c|}{ Starch \%* } \\
\hline & & \multicolumn{4}{|c|}{ year } & & \multicolumn{3}{|c|}{ year } & \\
\hline & & 2011 & 2013 & 2014 & 2015 & & 2013 & 2014 & 2015 & \\
\hline 1. & Control - without fertilizers & 17.5 & 12.3 & 10.9 & 13.7 & 13.6 & 70.8 & 66.3 & 68.1 & 68.4 \\
\hline 2. & Ammonium sulphate & 16.9 & 12.2 & 10.7 & 13.4 & 13.3 & 68.8 & 67.3 & 68.1 & 68.1 \\
\hline 3. & Urea & 17.1 & 12.2 & 10.9 & 13.4 & 13.4 & 68.9 & 66.5 & 68.0 & 67.8 \\
\hline 4. & $\begin{array}{l}\text { Tradecorp } \mathrm{Cu}+\text { Tradecorp } \mathrm{Mn}+ \\
\text { Tradecorp } \mathrm{Zn}\end{array}$ & 17.3 & 12.1 & 10.9 & 13.2 & 13.5 & 70.1 & 66.1 & 67.9 & 68.0 \\
\hline 5. & Delfan & 17.3 & 12.3 & 11.2 & 13.5 & 13.6 & 39.2 & 66.3 & 66.5 & 57.3 \\
\hline 6. & $\begin{array}{l}\text { Ammonium sulphate }+ \text { Tradecorp Cu }+ \\
\text { Tradecorp Mn + Tradecorp } \mathrm{Zn}+\text { Delfan }\end{array}$ & 16.9 & 12.0 & 10.9 & 13.5 & 13.3 & 69.9 & 66.6 & 67.2 & 67.8 \\
\hline & $\mathrm{LSD}_{05}$ & 0.82 & 0.87 & 0.77 & 1.24 & 0.62 & 2.51 & 1.59 & 0.98 & 1.44 \\
\hline
\end{tabular}

* - absolutely dry matter

In some years, wheat yields ranged from 4.20 to $6.70 \mathrm{t} \mathrm{ha}^{-1}$ but the average yield of spring wheat grain during the experiment in 2011-2015 was 5.26 $\mathrm{t} \mathrm{ha}^{-1}$ (Table 5). According to the average data of five years, foliar fertilization did not increase grain yield statistically significantly, nevertheless, in 2013 and 2014 statistically significant yield increases were obtained. Foliar fertilization with $\mathrm{N}$ and $\mathrm{S}$ fertilizer (ammonium sulphate) in treatment 2 increased grain yield by $6.2 \%$ and $3.5 \%$ in 2013 and 2014, and fertilization with urea (treatment 3 ) - by $7.0 \%$ and $4.2 \%$, respectively. In 2013 , the grain yield was increased by $7.0 \%$ by applying a fertilizer with amidic nitrogen and amino acids Delfan (treatment 5).

Meanwhile, foliar fertilization increased the straw yield only in 2011, i.e. only during one year out of five (Table 6). That year foliar fertilization with urea (treatment 3 ) increased the straw yield by $12.4 \%$, fertilizer containing amidic nitrogen and amino acids Delfan (treatment 5) - by $17.1 \%$, and fertilizer containing of S, amino acids and microelements (treatment 6 ) - by $21.8 \%$. Thus, the influence of foliar fertilization on the yields of spring wheat grain and straw manifested itself 
Table 5. The influence of foliar fertilization on grain yield of spring wheat

\begin{tabular}{llccccccc}
\hline \multirow{2}{*}{ No. } & \multicolumn{1}{c}{ Treatment } & \multicolumn{3}{c}{ Year } & \multicolumn{3}{c}{$\begin{array}{c}\text { Increase } \\
\%\end{array}$} \\
\cline { 3 - 7 } & & 2011 & 2012 & 2013 & 2014 & 2015 & & - \\
\hline 1. & Control - without fertilizers & 4.21 & 4.43 & 5.02 & 5.70 & 6.70 & 5.21 & - \\
2. & Ammonium sulphate & 4.26 & 4.45 & 5.33 & 5.90 & 6.63 & 5.31 & 1.92 \\
3. & Urea & 4.18 & 4.30 & 5.37 & 5.94 & 6.84 & 5.32 & 2.11 \\
4. & Tradecorp Cu + Tradecorp Mn + Tradecorp Zn & 4.22 & 4.35 & 5.25 & 5.81 & 6.57 & 5.24 & 0.58 \\
5. & Delfan & 4.19 & 4.30 & 5.37 & 5.82 & 6.77 & 5.29 & 1.54 \\
6. & Ammonium sulphate + Tradecorp Cu + & 4.13 & 4.33 & 5.08 & 5.73 & 6.70 & 5.19 & -0.38 \\
\hline & $\quad$ Tradecorp Mn + Tradecorp Zn + Delfan & 0.223 & 0.202 & 0.264 & 0.194 & 0.266 & 0.150 \\
\hline
\end{tabular}

Table 6. The influence of foliar fertilization on straw yield of spring wheat

\begin{tabular}{|c|c|c|c|c|c|c|c|c|}
\hline \multirow{2}{*}{ No. } & \multirow{2}{*}{ Treatment } & \multicolumn{5}{|c|}{ Year } & & \multirow{2}{*}{$\begin{array}{c}\text { Increase } \\
\%\end{array}$} \\
\hline & & 2011 & 2012 & 2013 & 2014 & 2015 & & \\
\hline 1. & Control - without fertilizers & 1.70 & 2.40 & 2.05 & 2.02 & 2.03 & 2.04 & - \\
\hline 2. & Ammonium sulphate & 1.77 & 2.30 & 2.04 & 2.16 & 2.10 & 2.07 & 1.47 \\
\hline 3. & Urea & 1.91 & 2.41 & 2.16 & 2.11 & 2.13 & 2.14 & 4.90 \\
\hline 4. & Tradecorp Cu + Tradecorp Mn + Tradecorp Zn & 1.79 & 2.32 & 2.06 & 2.08 & 2.07 & 2.06 & 0.98 \\
\hline 5. & Delfan & 1.99 & 2.27 & 2.13 & 2.06 & 2.10 & 2.11 & 3.43 \\
\hline 6. & $\begin{array}{l}\text { Ammonium sulphate }+ \text { Tradecorp } \mathrm{Cu}+ \\
\text { Tradecorp } \mathrm{Mn}+\text { Tradecorp } \mathrm{Zn}+\text { Delfan }\end{array}$ & 2.07 & 2.15 & 2.11 & 2.13 & 2.12 & 2.11 & 3.43 \\
\hline & $\mathrm{LSD}_{05}$ & 0.182 & 0.276 & 0.180 & 0.154 & 0.270 & 0.110 & \\
\hline
\end{tabular}

only in one year. During the experiment we tried to find correlation between the grain yield and quality, the grain yield and plant productivity indicators, however, no correlation was obtained. A negative correlation was found only in 2011 between the 1000 grain weight and crop density $(r=-0.522 * *)$.

\section{Discussion}

The results obtained from the research revealed that foliar fertilization of spring wheat increased the grain yield only in two years out of five, and the average yield increase resulting from the foliar fertilization during all five years was $-0.38-+2.11 \%$. So, intensive cultivation technology of spring wheat foliar fertilization should be interpreted cautiously. Today, fertilizer manufacturing industry is highly specialisedandadvanced in this particular field and the range of foliar fertilizers manufactured is very broad. Positive influence of foliar fertilization with the recommended nutrients and biostimulants $-\mathrm{N}, \mathrm{S}$, amino acids and microelements on plant physiology was proved (Kalajia et al., 2014; Skwierawska et al., 2016) and was done field experiments with different plants (Brar, Kaur, 2006; Staugaitis, Petrauskienè, 2006; Peng et al., 2013; Mekdad, Rady, 2016). However, when applying foliar fertilization, soil and its agrochemical properties should be considered. The influence of foliar fertilization is directly related to the deficiency of chemical elements essential for plants, and this influence is only marginally observed when these elements are in abundance. This is what we tried to analyse in our work. The soil was fertile and we adjusted optimal fertilizer rates according to each year's content of plant-available $\mathrm{P}_{2} \mathrm{O}_{5}, \mathrm{~K}_{2} \mathrm{O}, \mathrm{N}$ and $\mathrm{S}$. Thus the result obtained was consistent - there was no need for foliar fertilization of spring wheat, and positive results were observed only in individual years.

Nevertheless, foliar fertilization required assessment in a different aspect as well. It is a measure of reducing plant stress. Stress occurs due to unfavourable meteorological conditions - high or low air temperature, drought, short- or long-term water logging, etc. (Doflerus, 2014; Trnka et al., 2014). During our research we observed significant variations of air temperature and rainfall between years and within a year. Therefore, we believe that a single foliar spraying of spring wheat during the tillering stage could be insufficient, because to the formation of the grain in the ear passes a long time. Therefore, it is likely that one more foliar spraying should influence the positive impact of foliar fertilizers for wheat. The positive influence of two spraying applications with foliar fertilizers was observed for spring barley (Staugaitis, Petrauskiene, 2006) and sugar beet (Jakienè, 2011). It is also important to assess the influence of the same foliar fertilizer on different species of crops, because spraying of spring barley with ammonium sulphate or urea resulted in a larger yield increase (Staugaitis et al., 2014) compared with the spring wheat of this experiment. Accurate forecasting of plant demand for vital nutrients should be performed according to the chemical composition of leaves (Breuer et al., 2003), which proved correct in the experiments with spring barley (Staugaitis et al., 2014). As ammonium sulphate and urea were distinguished for their positive effect on spring wheat in two years out of five in this research, therefore, the prospects of using them for foliar fertilization are perhaps the most promising. 


\section{Conclusions}

1. Foliar fertilization of spring wheat at the $\mathrm{BBCH} 29-30$ stage with amino acids and amide nitrogen (Delfan $21 \mathrm{ha}^{-1}$ ) or microelements (Tradecorp $\mathrm{Cu} 0.8 \mathrm{~kg} \mathrm{ha}^{-1}$, Tradecorp Mn $1.0 \mathrm{~kg} \mathrm{ha}^{-1}$ and Tradecorp $\mathrm{Zn} 1.0 \mathrm{~kg} \mathrm{ha}^{-1}$ ) increased grain yield only in one year out of five.

2. Foliar fertilization of spring wheat at the $\mathrm{BBCH}$ 29-30 stage with ammonium sulphate $\left(15.0 \mathrm{~kg} \mathrm{ha}^{-1}\right)$ and urea $\left(6.7 \mathrm{~kg} \mathrm{ha}^{-1}\right)$ increased grain yield in two years out of five.

3. The applied foliar fertilizers did not have significant influence on the number of plants per area unit, number of grains per ear and the content of crude protein and starch accumulated in grain.

Received 11102016

Accepted 13012017

\section{References}

Babaeian M., Tavassoli A., Ghanbari A., Esmaeilian Y., Fahimifard M. 2010. Effects of foliar micronutrient application on osmotic adjustments, grain yield and yield components in sunflower (Alstar cultivar) under water stress at three stages. African Journal of Agricultural Research, 6 (5): 1204-1208

Begum K., Sikder A. H. F., Khanom S., Hossain Md. F., Parveen Z. 2015. Nutrient uptake by plants from different land types of Madhupur soils. Bangladesh Journal of Scientific Research, 28 (2): 113-121 https://doi.org/10.3329/bjsr.v28i2.26782

Brar M. S., Kaur N. 2006. Effect of soil and foliar applied potassium and nitrogen on yield of potato (Solanum tuberosum) in alluvial soils of Punjab, India. The Indian Journal of Agricultural Sciences, 76 (12): 740-743

Breuer J., König V., Merkel D., Olfs H. W., Steingrobe B., Stimpfl E., Wissemeier A., Zorn W. 2003. Plant analysis for the diagnosis of the nutritional status of crops. Agrimedia: 33-35 (in German)

Bundinienė O., Viškelis P., Zalatorius V. 2007. Influence of the additional fertilization through leaves on red beet yield and crop-root quality. Sodininkyste ir daržininkystė, 26 (1): 108-118 (in Lithuanian)

Cakmak I. 2008. Enrichment of cereal grains with zinc: agronomic or genetic biofortification? Plant and Soil, 302: $1-17$ https://doi.org/10.1007/s11104-007-9466-3

Doflerus R. 2014. To grow or not to grow: a stressful decision for plants. Plant Science, 229: 247-261

https://doi.org/10.1016/j.plantsci.2014.10.002

Fageria N. K., Baligar V. C. 2005. Nutrient availability. Hillel D. (ed.). Encyclopedia of soils in the environment. San Diego, USA, p. 63-71 https://doi.org/10.1016/b0-12-348530-4/00236-8

Fageria N. K., Baligar V. C., Clark R. B. 2006. Physiology of crop production. Binghamton, USA, $345 \mathrm{p}$.

Guenis A., Alpaslan M., Unal A. 2003. Effects of boron fertilization on the yield and some yield components of bread and durum wheat. Turkish Journal of Agriculture, 27: $329-335$
Imran M., Gurmani Z. A. 2011. Role of macro and micro nutrients in plant growth and development. Science, Technology and Development, 30 (3): 36-40

Jakienė E. 2011. Effect of biological products on sugar-beet crop. Žemès ūkio mokslai, 18 (2): 64-71 (in Lithuanian)

Kalajia H. M., Oukarroumb A., Alexandrovc V., Kouzmanovac M., Bresticd M., Zivcakd M., Samborskaa I. A., Cetnera M. D., Allakhverdieve S. I., Goltsevc V. 2014. Identification of nutrient deficiency in maize and tomato plants by in vivo chlorophyll a fluorescence measurements. Plant Physiology and Biochemistry, 81: 16-25 https://doi.org/10.1016/j.plaphy.2014.03.029

Malhi S. S., Cowell L., Kutcher H. R. 2005. Relative effectiveness of various sources, methods, times and rates of copper fertilizers in improving grain yield of wheat on a Cu-deficient soil. Canadian Journal of Plant Science, 85 (1): 59-65 https://doi.org/10.4141/P04-089

Mekdad A. A. A., Rady M. M. 2016. Response of Beta vulgaris $\mathrm{L}$. to nitrogen and micronutrients in dry environment. Plant, Soil and Environment, 62 (1): 23-29 https://doi.org/10.17221/631/2015-PSE

Peng S. H., Wan-Azha W. M., Wong W. Z., Go W. Z., Chai E. W. 2013. Effect of using agro-fertilizers and $\mathrm{N}$-fixing azotobacter enhanced biofertilizers on the growth and yield of corn. Journal of Applied Sciences, 13 (3): 508-512 https://doi.org/10.3923/jas.2013.508.512

Pranckietienė I., Mažuolytė-Miškinė E., Pranckietis V., Dromantienè R., Šidlauskas G., Vaisvalavičius R. 2015. The effect of amino acids on nitrogen, phosphorus and potassium changes in spring barley under the conditions of water deficit. Zemdirbyste-Agriculture, 102 (3): 265-272 https://doi.org/10.13080/z-a.2015.102.034

Sepiedeh Z., Mohammad N., Hamid R. T. M., Hossein Z. 2014 Effect of zinc and sulfur foliar applications on physiological characteristics of sunflower (Helianthus annuus L.) under water deficit stress. International Journal of Biosciences, 5 (12): 87-96 https://doi.org/10.12692/ijb/5.12.87-96

Sierra C. A., Trumbore S. E., Davidson E. A., Vicca S., Janssens I. 2015. Sensitivity of decomposition rates of soil organic matter with respect to simultaneous changes in temperature and moisture. Journal of Advances in Modeling Earth Systems, 7 (1): 335-356 https://doi.org/10.1002/2014MS000358

Skwierawska M., Benedycka Z., Jankowski K., Skwierawski A. 2016. Sulphur as a fertiliser component determining crop yield and quality. Journal of Elementology, 21 (2): 609-623

Staugaitienė R., Šlepetienè A., Žičkienè L. 2013. The effect of sulphur fertilisation on grain yield and quality of spring wheat. Žemès ūkio mokslai, 20 (4): 266-275 (in Lithuanian)

Staugaitis G., Petrauskienė R. 2006. Leaf-feed fertiliser effect on the yield, quality and profitability of malt barley crop. Zemdirbyste-Agriculture, 93 (2): 54-64 (in Lithuanian)

Staugaitis G., Pečkytė A. 2008. Effect of mineral fertilisers with different composition on yield, grain size parameters and quality of malting barley. Vagos, 80 (33): 108-116

Staugaitis G., Brazienė Z., Marcinkevičius A., Mažeika R., Antanaitis Š., Staugaitienè R. 2014. Spring barley as affected by nitrogen and sulphur fertiliser rates calculated using different diagnostic methods lands. ZemdirbysteAgriculture, 101 (4): 373-380 https://doi.org/10.13080/z-a.2014.101.047 
Trnka M., Reimund P., Rötter R. P., Ruiz-Ramos M., Kersebaum K. Ch., Olesen J. E., Žalud Z., Semenov M. A. 2014. Adverse weather conditions for European wheat production will become more frequent with climate change. Nature Climate Change, 4: 637-643

https://doi.org/10.1038/nclimate2242
Wójcik P. 2004. Uptake of mineral nutrients from foliar fertilization. Journal of Fruit and Ornamental Plant Research, 12: 201-218

Zafar S., Ashraf M. Y., Anwar S., Noman A. 2016. Yield enhancement in wheat by soil and foliar fertilization of $\mathrm{K}$ and $\mathrm{Zn}$ under saline environment. Soil and Environment, 35 (1): 46-55

ISSN 1392-3196 / e-ISSN 2335-8947

Zemdirbyste-Agriculture, vol. 104, No. 2 (2017), p. 123-130

DOI $10.13080 / \mathrm{z}-\mathrm{a} .2017 .104 .016$

\title{
Tręšimo per lapus azotu, siera, aminorūgštimis ir mikroelementais įtaka vasariniams kviečiams
}

\author{
G. Staugaitis ${ }^{1}$, L. Aleknavičienèं ${ }^{2}$ Z. Braziene் ${ }^{2}$, A. Marcinkevičius ${ }^{2}$, V. Paltanavičius ${ }^{1}$ \\ ${ }^{1}$ Lietuvos agrarinių ir miškų mokslų centro Agrocheminių tyrimų laboratorija \\ ${ }^{2}$ Lietuvos agrarinių ir miškų mokslų centro Rumokų bandymų stotis
}

\section{Santrauka}

Giliai glejiškame karbonatingame išplautžemyje (IDk-g0), kuriame vyravo dulkiškas lengvas priemolis ant sunkaus priemolio, penkerius metus (2011-2015 m.) vykdyti tyrimai su vasariniais kviečiais. Tyrimų tikslas nustatyti, kaip pagrindinio tręšimo metu optimaliai azotu, fosforu, kaliu ir siera tręštuose vasariniuose kviečiuose veikia ịvairios lapų trąšos. Dirvožemis buvo gerai sukultūrintas, turintis daug judriųų fosforo ir kalio, $\mathrm{pH}_{\mathrm{KCl}} 6,4-$ 7,4. Atsižvelgiant ị pavasarị atliktus dirvožemio agrocheminius tyrimus, kiekvienais metais visiems variantams buvo išbertos vienodos normos mineralinių trąšų. Tyrimų metu nustatyta, kad vasarinių kviečių tręšimas per lapus BBCH 29-30 tarpsniu aminorūgštimis su amidiniu azotu (Delfan 21 ha $^{-1}$ ) arba mikroelementais (Tradecorp Cu 0,8 $\mathrm{kg} \mathrm{ha}^{-1}$, Tradecorp Mn 1,0 $\mathrm{kg} \mathrm{ha}^{-1}$ ir Tradecorp Zn 1,0 $\mathrm{kg} \mathrm{ha}^{-1}$ ) grūdų derlių didino tik vienus metus iš penkerių, o amonio sulfatas $\left(15.0 \mathrm{~kg} \mathrm{ha}^{-1}\right)$ ir karbamidas $\left(6,7 \mathrm{~kg} \mathrm{ha}^{-1}\right)-$ dvejus metus. Penkerių metu vidutiniais duomenis, naudotos lapų trąšos grūdų ir šiaudų derliaus esmingai nedidino ir dèsningos įtakos žalių baltymų bei krakmolo kiekiui grūduose neturèjo.

Reikšminiai žodžiai: aminorūgštys, azotas, lapų trąšos, mikroelementai, siera, vasariniai kviečiai. 